\title{
Inflammation Mediated Down-Regulation of Hepatobiliary Transporters Contributes to Intrahepatic Cholestasis and Liver Damage in Murine Biliary Atresia
}

\author{
HUIQI YANG, TORSTEN PLÖSCH, TON LISMAN, ANNETTE S. H. GOUW, ROBERT J. PORTE, HENKJAN J. VERKADE,
} AND JAN B. F. HULSCHER

\author{
Departments of Surgery [H.Y., T.L., R.J.P., J.B.F.H.], Pathology [A.S.H.G.], Pediatrics [T.P., H.J.V.], and Pediatrics and Pediatric \\ Gastroenterology [H.J.V.], Beatrix Children's Hospital, University Medical Center Groningen, University of Groningen, Groningen 9700 \\ RB, The Netherlands; Department of Surgery [H.Y.], Tianjin Medical University, Tianjin 300100, China
}

\begin{abstract}
To investigate the hypothesis that during the development of biliary atresia, early changes in hepatobiliary transport are mainly related to the inflammatory process and lead to intrahepatic cholestasis and subsequent liver injury, livers from mice with rhesus rotavirus-induced biliary atresia were analyzed for mRNA expression of hepatobiliary transporters, nuclear receptors, and inflammatory cytokines. Seven days after inoculation, despite high bile acid concentrations in the liver, gene expression of canalicular and basolateral hepatobiliary transporters and their regulatory nuclear receptors was down-regulated with concomitant increase in gene expression of inflammatory cytokines and rise in serum unconjugated bilirubin. At $14 \mathrm{~d}$, hepatobiliary transporters and nuclear receptors remained down-regulated although the inflammatory response subsided. The percentage of conjugated bilirubin started to increase as extrahepatic biliary obstruction occurred. At $18 \mathrm{~d}$, expression of hepatobiliary transporters remained low, expression of nuclear receptors returned to normal, while expression of inflammatory cytokines decreased further. Moreover, histology demonstrated progressive inflammation, bile duct damage, ductular proliferation, and hepatocyte necrosis. In conclusion, intrahepatic cholestasis due to inflammation-related down-regulation of basolateral and canalicular hepatobiliary transporters is an early event in the development of biliary atresia. Intrahepatic cholestasis contributes to the development of jaundice and liver injury. (Pediatr Res 66: 380-385, 2009)
\end{abstract}

$\mathrm{C}$ hanges in the expression of hepatobiliary transporters provide a crucial mechanism to regulate bile acid homeostasis and to prevent hepatic bile acid toxicity in hepatocytes during cholestasis (1-7). The basolateral transporters, sodium-taurocholate cotransporting polypeptide (Ntcp; Slc10a1) and organic anion-transporting polypeptide (Oatp; S121a), are the major transporters for the uptake of bile acids and organic solutes from blood into the hepatocyte.

The canalicular transporters bile salt export pump (Bsep; Abcb11), multidrug resistance-associated protein 2 (Mrp2; Abcc), and multidrug resistance protein (Mdr2; Abcb4) are responsible for the excretion of bile salts, organic anions, and phospholipids into bile.

Received March 19, 2009; accepted June 2, 2009

Correspondence: Jan B. F. Hulscher, M.D., Ph.D., Department of Pediatric Surgery, Beatrix Children's Hospital, University Medical Center Groningen, Groningen 9700 RB, The Netherlands; e-mail: j.b.f.hulscher@chir.umcg.nl

Supported by a Gastrostart grant from The Netherlands Society of Gastroenterology and a grant from the Jan Kornelis de Cock Foundation.
The nuclear receptors Farnesoid X receptor (FXR, NR1H4) and Pregnane X receptor (PXR, NR1I2) also play an important role in the regulation of bile acid metabolism. High bile acid levels can activate FXR, which directly or indirectly induces Bsep expression.

Different forms of cholestasis may exhibit different transport regulatory mechanisms. Although bile duct ligation and lipopolysaccharide (LPS)-induced cholestasis are two wellstudied cholestasis models, little is known about regulation of hepatobiliary transport during the development of biliary atresia (BA). BA is a progressive inflammatory fibro-obliteration of the extrahepatic biliary tree of the neonate of unknown etiology.

The rhesus rotavirus (RRV)-induced biliary atresia mouse model offers the possibility to longitudinally study both acute and chronic cholestatic responses. It demonstrates many key features of human biliary atresia $(8,9)$. In this model, RRVinduced intra and extrahepatic inflammation of the bile ducts is followed by progressive inflammatory extrahepatic bile duct obstruction $(10,11)$ This is different from mechanically induced biliary obstruction like bile duct ligation models (BDL).

Although the RRV BA model is based on a pan-cholangitis, hepatobiliary transport may also be altered during the early development of biliary atresia as the result of the inflammation itself. In this study, we hypothesized that early changes in hepatobiliary transport due to inflammation might lead to intrahepatic cholestasis even before obstruction of the extrahepatic bile duct occurs, thus contributing to early liver damage.

\section{METHODS}

Infection of newborn mice with rhesus rotavirus. Adult, pregnant virusfree Balb/c mice were purchased from Harlan (The Netherlands). Mice received care in compliance with the guidelines of the local animal ethics committee according to the Experiments on Animals Act (1996) issued by the Netherlands Ministry of Public Health, Welfare, and Sports.

Within $18 \mathrm{~h}$ after birth, the newborn pups were infected intraperitoneally with $20 \mu \mathrm{L} 1 \times 10^{6}$ plaque-forming units of the MMU18006 strain of RRV, provided by Professor Claus Petersen (Medical School Hannover, Germany). Mice in the control group were injected with $20 \mu \mathrm{L} 0.9 \%$ saline. Infected mice

\footnotetext{
Abbreviations: BA, biliary atresia; BSEP, bile salt export pump; FXR, farnesoid X receptor; NTCP, sodium-dependent taurocholate cotransporting polypeptide; PXR, pregnane $\mathrm{X}$ receptor; RRV, rhesus rotavirus
} 
that died within the first $6 \mathrm{~d}$ or that were not fed by their mothers after infection were excluded from the study. All mice were weighed daily and were examined for jaundice, acholic stools, and urine bilirubin (using urinalysis reagent strips; Bayer Corp, USA). Mice were planned to be killed at 7, 14, and $21 \mathrm{~d}$ after RRV infection or saline injection. As sick mice began to lose weight after $14 \mathrm{~d}$, we terminated the last group at $18 \mathrm{~d}$ of age instead of $21 \mathrm{~d}$.

At these three time points, blood samples were collected by cardiac puncture for determination of serum liver enzymes. The gross appearance of liver, gall bladder, and common bile duct was recorded, and the organs were harvested and frozen into liquid nitrogen for RNA isolation or stored for histologic analysis.

Liver function and bile acid measurement. Serum liver enzymes including alanine aminotransferase (ALAT), gamma-glutamyl transferase ( $\gamma$-GT), and serum bilirubin were assessed using the Ektachem DT60 [Pi] system and DTSC [Pi] Module (Johnson \& Johnson Clinical Diagnostics Inc., Rochester, NY). For the determination of bile acids, parts of the livers of mice killed at the same time point were pooled and crunched in liquid nitrogen. They were transferred in a total volume of $1.2 \mathrm{~mL}$ of $0.9 \%(\mathrm{wt} / \mathrm{vol}) \mathrm{NaCl}$. One hundred fifteen microliters $10 \mathrm{M} \mathrm{NaOH}$ solution and $1.4 \mathrm{~mL}$ of methanol were added and this solution was incubated at $80^{\circ} \mathrm{C}$ for $2 \mathrm{~h}$. After cooling to room temperature, $25 \mathrm{~mL}$ of water was added. After mixing and centrifuging $10 \mathrm{~min}$ at $2500 \mathrm{rpm}, 100 \mu \mathrm{L}$ of supernatant was measured enzymatically (12).

Histology and immunohistochemistry. Frozen sections of liver and bile duct (4- $\mu \mathrm{m}$ thickness) were stained with hematoxylin and eosin. Sections were also immunostained for cytokeratin 19, using Cytokeratin19 polyclonal rabbit antibody (Abcam, Cambridge, UK). Horseradish peroxidase (HRP)labeled goat anti-rabbit IgG (Dako, Denmark) was used as a secondary antibody. HRP-labeled rabbit anti-goat IgG (Dako, Denmark) was used as a tertiary antibody.

For Ki67/cytokeratin 19 double staining, sections were immunostained for Ki67, using Ki67 monoclonal rabbit antibody (Novus Biologic, USA) as a first, goat anti-rabbit IgG-HRP antibody (Dako, Denmark) as a secondary, and rabbit anti-goat IgG-HRP antibody (Dako, Denmark) as a tertiary antibody. The staining reaction was developed with AEC (3-amino-9 ethyl-carbazole). Afterward, sections were incubated with cytokeratin19 antibody (polyclonal rabbit antibody, Abcam, Cambridge, UK) using goat anti-rabbit with an alkaline phosphatase label (Dako, Denmark) as secondary antibody. The staining reaction was developed with solution of fast blue.

Mouse skin was used as a positive control; RRV infected mice liver exposed to $1 \% \mathrm{BSA} / \mathrm{PBS}$ instead of a primary antibody was used as negative control.
All histologic studies were assessed by one pathologist (A.S.H.G.) who was unaware of other study data.

Gene expression. Total RNA was extracted from frozen liver by RNeasy Mini Kit (Qiagen GmbH, Germany). After incubation with RNase-free DNase I (Invitrogen Life Technologies), reverse transcription was performed with SuperScript II reverse transcriptase and oligo (dT) (Invitrogen Life Technologies CITY). Three microliters cDNA (1:20 diluted) was subjected to realtime PCR using the Taqman system in a ABIPRISM 7900HT Sequence Detector System (Applied Biosystem, Foster City, CA) to quantify expression of target genes. PCR amplifications were performed with specific primers and probes (Table 1). Primers were designed by using Primer Express Software (Applied Biosystem). Data were analyzed with Sequence Detector System 2.3 (Applied Biosystem). The levels of gene expression were calculated as a ratio to the house keeping gene $\beta$-actin.

Membrane isolation and western blotting. For isolation of total liver membranes, liver tissue was homogenized in $1 \mathrm{mM} \mathrm{NaHCO}$ ( $\mathrm{pH} 7.4$ ), containing complete protease inhibitor cocktail (Roche, Almere, The Netherlands). Homogenates were gauze filtered, and total membranes were isolated by centrifugation at $100,000 \times \mathrm{g}$ for $1 \mathrm{~h}$ at $4^{\circ} \mathrm{C}$. Membrane pellets were resuspended in $10 \mathrm{mM}$ Tris $/ 250 \mathrm{mM}$ sucrose, $\mathrm{pH} 7.4$, containing complete protease inhibitor cocktail and stored at $-80^{\circ} \mathrm{C}$. Protein was determined according to Lowry et al. (13).

Total liver membranes were electrophoresed through polyacrylamide gels (7\% for Ntcp; 5\% for Bsep). Proteins were blotted onto a nitrocellulose filter (Amersham, Little Chalfont, UK) by tank blotting. Ponceau S staining was performed to check for equal protein transfer. Filters were blocked in trisbuffered saline ( $\mathrm{pH}$ 7.4) containing $0.1 \%$ Tween 20 and $4 \%$ skim milk powder. Blots were incubated with polyclonal primary antibodies against Ntcp (14) or Bsep (15). After washing, immunocomplexes were detected using horseradish peroxidase conjugated donkey anti-rabbit IgG and Super Signal West Pico chemiluminescent substrate (Thermo Scientific, Etten-Leur, The Netherlands). Band densities were determined by using a Gel Doc XR (Bio-Rad, Hercules, CA).

Because of the limited amount of tissue available and the large amount of tissue needed for western blots, only Ntcp and Bsep were studied at $14 \mathrm{~d}$. This time point was chosen as it demonstrated the most significant down-regulation of mRNA expression.

Statistics. The differences of mean expression levels between control and rotavirus-infected groups were compared per time point using independentsamples $t$ test or Mann Whitney $U$ test as appropriate. A $p$ value $<0.05$ was

Table 1. Sequences of primers, probes, and PCR product sizes for amplified products

\begin{tabular}{|c|c|c|c|c|}
\hline Gene (Gene ID) & Primers & Probes & $\begin{array}{c}\text { Annealing } \\
\text { temperature }\left({ }^{\circ} \mathrm{C}\right)\end{array}$ & $\begin{array}{l}\text { Product } \\
\text { size (bp) }\end{array}$ \\
\hline $\begin{array}{l}\beta \text {-actin (Actb) } \\
\quad(11461)\end{array}$ & $\begin{array}{l}\text { (F): 5'-AGCCATGTACGTAGCCATCCA } \\
\text { (R): 5'-TCTCCGGAGTCCATCACAATG }\end{array}$ & TGTCCCTGTATGCCTCTGGTCGTACCAC & 59 & 81 \\
\hline Tnfa (Tnf) (21926) & $\begin{array}{l}\text { (F): 5'-GTACCCACTCGTAGCAAAC } \\
\text { (R): 5'-AGTTGGTTGTCTTTGAGATCCATG }\end{array}$ & CGCTGGCTCAGCCACTCCAGC & 60 & 76 \\
\hline Ifng (15978) & $\begin{array}{l}\text { (F): 5'-CCAAGCGGCTGACTGAACTC } \\
\text { (R): 5'-TCACTGCAGCTCTGAATGTTTCTTAT }\end{array}$ & ACAGGCTGTCCCTGAAAGAAAGCAGTGTC & 60 & 82 \\
\hline I16 (IL6) (16193) & $\begin{array}{l}\text { (F): 5'-CCTTCCTACCCCAATTTCCAAT } \\
\text { (R): 5'-GTCCTTAGCCACTCCTTCTGTGA }\end{array}$ & AGTTGCCTTCTTGGGACTGATGCTGG & 60 & 68 \\
\hline $\begin{array}{l}\text { RRV-Nsp3 } \\
\text { (RRVgp1) } \\
\text { (1489706) }\end{array}$ & $\begin{array}{l}\text { (F): 5'-TGATTGGAAATCAAGATATGAACAGTTAG } \\
\text { (R): 5'-TTTCTAGCTTTAAGAACCCAATGATTATAC }\end{array}$ & TGAAAGAAAGCAGTGTCCAGGCTGT & 60 & 97 \\
\hline $\begin{array}{l}\text { Ntcp (Slc10a1) } \\
\quad(20493)\end{array}$ & $\begin{array}{l}\text { (F): 5'-ATGACCACCTGCTCCAGCTT } \\
\text { (R): 5'-GCCTTTGTAGGGCACCTTGT }\end{array}$ & CCTTGGGCATGATGCCTCTCCTC & 60 & 111 \\
\hline $\begin{array}{l}\text { Oatp1 (Slco1a1) } \\
\quad(28248)\end{array}$ & $\begin{array}{l}\text { (F): 5'-CAGTCTTACGAGTGTGCTCCAGAT } \\
\text { (R): 5'-ATGAGGAATACTGCCTCTGAAGTG }\end{array}$ & TGGATTTGCCAGTACATTTACCTTCTTGCC C & 60 & 111 \\
\hline $\begin{array}{l}\text { Bsep (Abcb11) } \\
\quad(27423)\end{array}$ & $\begin{array}{l}\text { (F): 5'-CTGCCAAGGATGCTAATGCA } \\
\text { (R): 5'-CGATGGCTACCCTTTGCTTCT }\end{array}$ & TGCCACAGCAAT TTGACACCCTAGTTGG & 60 & 117 \\
\hline $\begin{array}{l}\text { Mdr2 (Abcb4) } \\
\quad(18670)\end{array}$ & $\begin{array}{l}\text { (F): 5'-GCAGCGAGAAACGGAACAG } \\
\text { (R): 5'-GGTTGCTGATGCTGCCTAGTT }\end{array}$ & AAAGTCGCCGTCTAGGCGCCGT & 60 & 64 \\
\hline $\begin{array}{l}\operatorname{Mrp} 2(\text { Abcc2) } \\
\quad(12780)\end{array}$ & $\begin{array}{l}\text { (F): 5'-GGATGGTGACTGTGGGCTGAT } \\
\text { (R): 5'-GGCTGTTCTCCCTTCTCATGG }\end{array}$ & AGCTGCATCGTCAGGAAT TTC CTC CAC A & 60 & 83 \\
\hline $\begin{array}{l}\text { Fxr }(\mathrm{Nr} 1 \mathrm{~h} 4) \\
\quad(20186)\end{array}$ & $\begin{array}{l}\text { (F): 5'-CGCTGAGATGCTGATGTCTTG } \\
\text { (R): 5'-CCATCACTGCACATCCCAGAT }\end{array}$ & ATG ATC ACA AGT TCACCCCGCTCCTCT & 60 & 82 \\
\hline $\begin{array}{l}\text { Pxr (Nr1i2) } \\
\quad(18171)\end{array}$ & $\begin{array}{l}\text { (F): 5'-ATAGGGTTACAGCACGAACTCAGA } \\
\text { (R): 5'-GCCATTTCAGCTTGGTCTTCTT }\end{array}$ & CGAGCTGCTTCTGTGTTCCAGACGC & 60 & 68 \\
\hline $\begin{array}{l}\text { Shp (Nr0b2) } \\
\quad(23957)\end{array}$ & $\begin{array}{l}\text { (F): } 5^{\prime} \text {-AAG GGC ACG ATC CTC TTC AA } \\
\text { (R): 5'-CTG TTG CAG GTG TGC GAT GT }\end{array}$ & ATG TGC CAG GCC TCC GTG CC & 60 & 99 \\
\hline Cyp7a1 (13122) & $\begin{array}{l}\text { (F): 5'-CAG GGA GAT GCT CTG TGT TCA } \\
\text { (R): 5'-AGG CAT ACA TCC CTT CCG TGA }\end{array}$ & TGCAAAACCTCCAATCTGTCATGAGACCTC C & 60 & 121 \\
\hline
\end{tabular}


considered to be statistically significant. Statistics were performed using SPSS 12.0 (SPSS Inc., Chicago, IL).

\section{RESULTS}

Rotavirus infection results in biliary atresia. To induce murine BA, we infected the newborn mice intraperitoneally with RRV. One mouse died $3 \mathrm{~d}$ after infection and was excluded. Sixty-five percent of infected animals developed the phenotype of biliary atresia. Seven days after RRV infection, jaundice became apparent in affected mice, and elevated urine bilirubin levels could be detected. In affected mice, stenoses with or without prestenotic dilatations were visible in different parts of the biliary tree from $14 \mathrm{~d}$ onward, which is in accordance with the literature (9).

Viral infection and inflammatory response. To investigate the viral infection and inflammatory response, mRNA levels of RRV proteins and inflammatory cytokines were quantified by qPCR. In control mice, viral proteins were not detectable. In BA mice, expression of the RRV nonstructural protein $N s p 3$ peaked at $7 \mathrm{~d}$, dropped at $14 \mathrm{~d}$, and was undetectable at $18 \mathrm{~d}$ (Fig. 1). Similarly high levels of RRV structural protein (Vp6) were detected at $7 \mathrm{~d}$ in BA mice, which were not detectable at $14 \mathrm{~d}$ (data not shown). Expression of Ifng and Tnfa remained low in control mice. Their expression in BA mice was substantially higher than that of control mice at $7 \mathrm{~d}$. Ifng and Tnfa levels decreased rapidly at $14 \mathrm{~d}$ to return to normal at $18 \mathrm{~d}$. In healthy control mice, the expression of $I l 6$ remained low, while its expression in BA mice was significantly higher than the expression of control group at $14 \mathrm{~d}$, and decreased again at $18 \mathrm{~d}$ (Fig. 2).

Cholestasis and liver functions. To determine the reason for cholestasis and the extent of liver damage, serum bilirubin, serum liver enzymes, and bile salts in the liver were measured. In mice with BA, high levels of serum bilirubin were observed. At $1 \mathrm{wk}$, the high level of serum bilirubin was predominantly composed of unconjugated bilirubin. At 14 and $18 \mathrm{~d}$, the increase in serum bilirubin was predominantly due to conjugated bilirubin (Fig. 2), which increased more than 5 -fold compared with levels at $7 \mathrm{~d}$. Bile salts levels in the liver
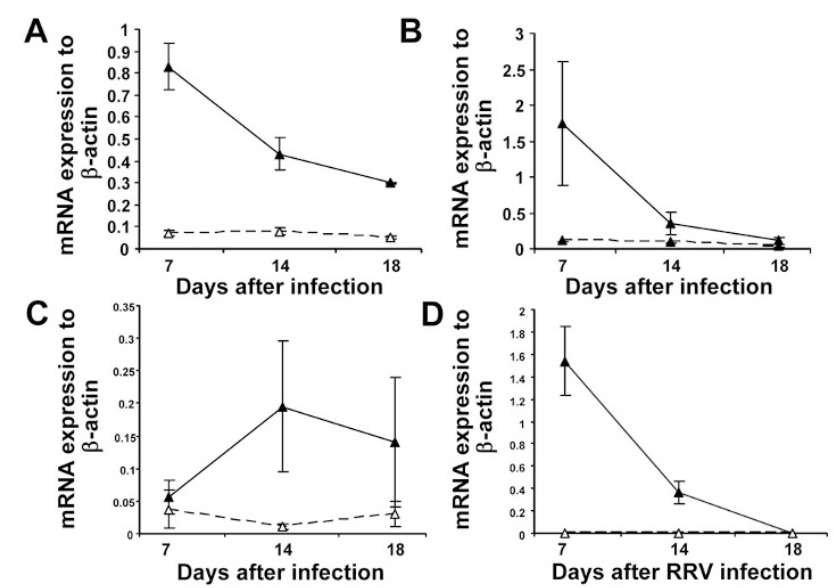

Figure 1. mRNA expression of Tnfa (A), Ifng $(B), I l 6(C)$ and mRNA expression of encoding RRV nonstructural protein $(N s p 3)(D)$ in BA mice $(\mathbf{\Delta})$ and control mice $(\triangle)$ at 7,14 , and $18 \mathrm{~d}$.
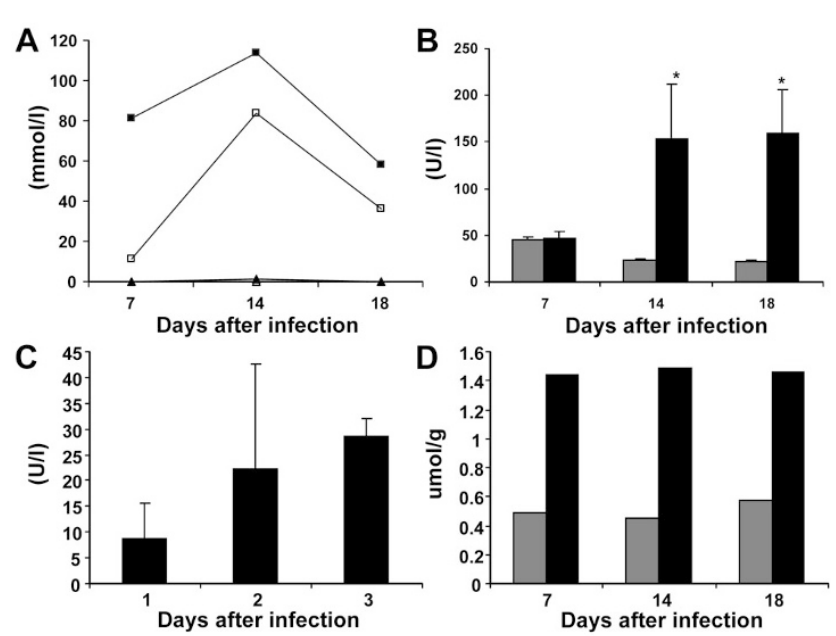

Figure 2. Serum bilirubin $(A)$ in BA mice (total bilirubin, $\mathbf{\square}$; direct bilirubin, $\square$ ) and control mice (total bilirubin, $\mathbf{\Delta}$; direct bilirubin, $\triangle$ ); alanine aminotransferase (ALAT) $(B)$, gamma-glutamyl transferase $(\gamma$-GT) levels $(C)$, and mean liver bile acid concentration $(D)$ in BA (black bars) and control mice (gray bars) at 7,14 , and 18 d. ${ }^{*} p<0.05$.

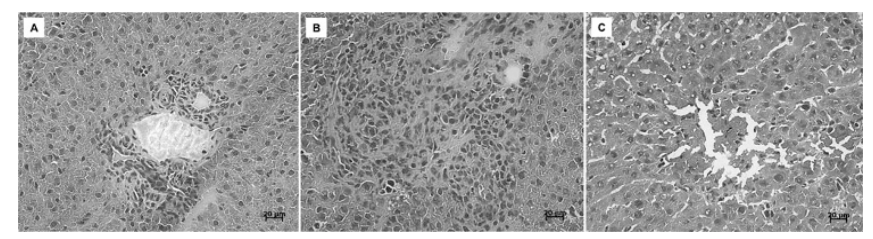

Figure 3. Hematoxylin and eosin staining showing normal portal tract morphology in control mice $(A$, magnification $\times 400)$, inflammation of the portal tracts in BA mice at $7 \mathrm{~d}(B$, magnification $\times 400)$, and liver necrosis in BA mice at $18 \mathrm{~d}(C$, magnification $\times 400)$.

were already profoundly higher in infected mice at $7 \mathrm{~d}$, even before direct hyperbilirubinemia developed. ALAT, as a marker of liver damage, increased significantly compared with controls at $14 \mathrm{~d}$ and remained so over time (Fig. 2). $\gamma$-GT, as a marker of cholestasis and cholangiocyte injury, was undetectable in healthy controls, while its level was increasing over time in BA mice (Fig. 3).

Liver histology. Hematoxylin and eosin staining showed a progressive infiltration of the portal tracts with lymphocytes, neutrophils, and macrophages from $7 \mathrm{~d}$ on (Fig. 3). In addition, hepatic necrosis could be detected at $18 \mathrm{~d}$. Cytokeratin 19 and cytokeratin 19/Ki67 double staining showed proliferation of ductular cells in both intra and extrahepatic bile ducts from $7 \mathrm{~d}$ on (Fig. 4).

Hepatobiliary transport mRNA expression of nuclear receptors and transporters. Expression of nuclear receptors and transporters is depicted in Figure 5. Expression of Fxr and Shp decreased, reaching significance at $14 \mathrm{~d}$. After $18 \mathrm{~d}$, expression of both nuclear receptors increased again reaching levels not significantly different from control mice. Down-regulation of Bsep paralleled the lower expression of Fxr, also reaching significance at $14 \mathrm{~d}$. A similar pattern was observed in the expression of Pxr, although differences compared with control mice were less pronounced.

Expression of Ntcp was lower in sick mice compared with control mice, reaching significance at $14 \mathrm{~d}$. In contrast to $\mathrm{Ntcp}$, 


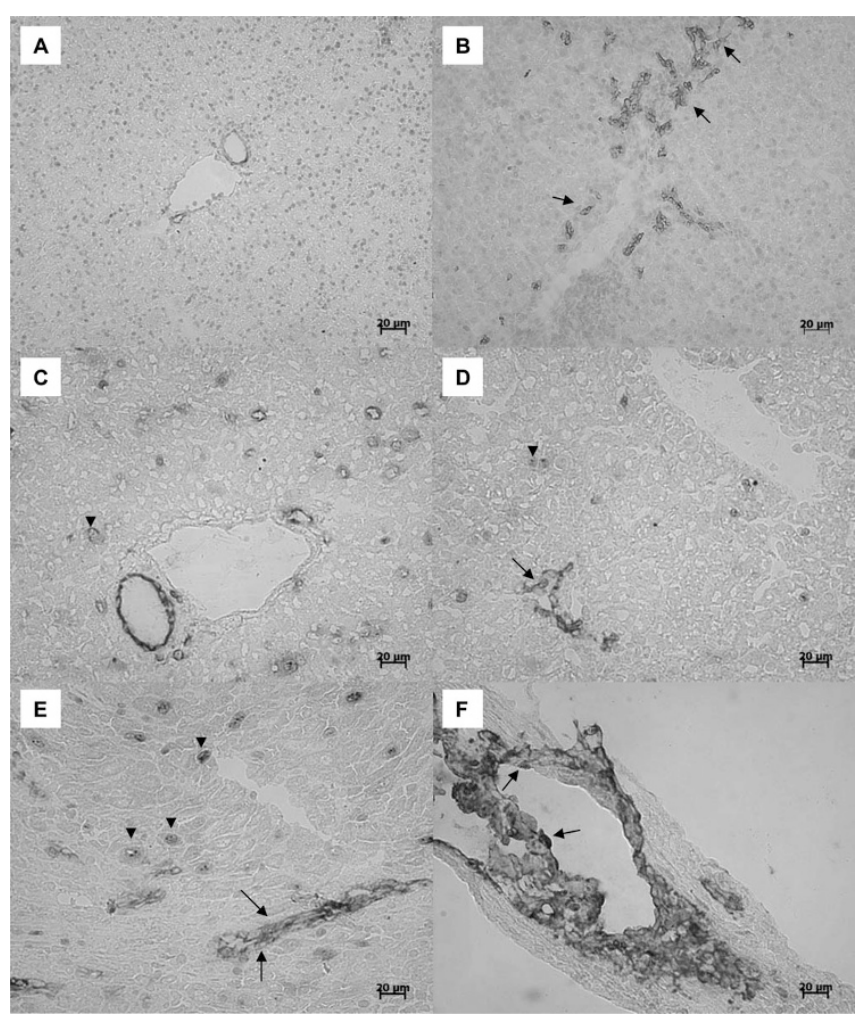

Figure 4. Ck19 staining of a normal portal tract $(A$, magnification $\times 200)$, and BA mice demonstrating ductular reaction (black arrow) at $14 \mathrm{~d}(B$, magnification $\times 200$ ). Double staining with ck19 (blue, cytoplasmic staining) and Ki67 (red, nuclear staining) demonstrating the absence of proliferation in the portal tracts in controls, Ki67 positive hepatocytes were present (arrow head) ( $C$, magnification $\times 400$ ). Ki67 positive nuclei of ductules (black arrow) and Ki67 positive hepatocytes (arrow head) were demonstrated in BA mice at $14 \mathrm{~d}(D$, magnification $\times 400)$. Ki67 positive nuclei of bile ducts (black arrow) and hepatocytes (arrow head) were also found in BA mice at $18 \mathrm{~d}(E$, magnification $\times 400)$. Ki67 positive nuclei of the extrahepatic duct (black arrow) were observed at $18(F$, magnification $\times 400) \mathrm{d}$ in BA mice.

the expression levels of Oatpl did not change during the experimental period. Significant down-regulation of Mrp2 was observed at $7 \mathrm{~d}$ and $14 \mathrm{~d}$. In comparison, the expression of $M d r 2$ remained relatively unchanged. The expression of Cyp7al of sick mice was significantly down-regulated at 7 and $14 \mathrm{~d}$.

Protein expression of canalicular and basolateral transporters. Protein levels in total liver membrane isolates were studied at $14 \mathrm{~d}$ after inoculation, as most significant changes on mRNA levels were observed at that time point. The protein level of Ntcp was significantly down-regulated while the protein level of Bsep was up-regulated compared with the control group (Fig. 6).

\section{DISCUSSION}

We hypothesized that inflammation might lead to a downregulation of hepatobiliary transport in the RRV induced BA model. We demonstrated that inflammation-related downregulation of basolateral and canalicular hepatobiliary transporters led to intrahepatic cholestasis, which might contribute to the progressive liver damage observed in this model.

One week after inoculation, there was a marked inflammatory response. This coincided with down-regulation of the canalicuar and basolateral transporters Bsep, Mrp2, and Ntcp. At that time, jaundice was mainly due to unconjugated bilirubin. Despite high bile acid levels in the liver, mRNA levels of Fxr, Shp, and Pxr started to decrease. At 14 d, mRNA expression of RRV-Nsp3, Tnfa, Ifng decreased, while Il6 peaked. Hepatobiliary transporter expression remained decreased. At this point, the high bilirubin levels consisted mainly of conjugated bilirubin, suggestive of bile duct obstruction, which could indeed be observed microscopically. At $18 \mathrm{~d}$, the expression of inflammatory cytokines, hepatobiliary transporters, and the nuclear receptors normalized. These changes might be attributed to the high concentration of bile acids in the absence of an inflammatory response (1).

Histology demonstrated a ductular reaction and proliferation of cholangiocytes, similar to the changes observed in human biliary atresia. There was progressive liver injury culminating in liver necrosis, which may be due to bile acid toxicity.

There are various models of experimental cholestasis in animals. One of the most widely studied is the BDL. After BDL, there is down-regulation of Ntcp mRNA. This is considered to prevent further bile acid uptake by hepatocytes (16). Oatp1 and Mrp2 are down-regulated as well $(17,18)$ while Bsep mRNA expression is maintained. This might reduce the extent of liver injury produced by bile acid retention (19). Many of these effects are induced via activation of Fxr due to the accumulation of bile acids.

Another model is the LPS-induced (inflammatory) cholestasis model $(20-26)$. In this model, there is a marked downregulation of Ntcp, Mrp2 but also a down-regulation of Bsep mRNA expression. Several inflammatory cytokines such as Tnfa, Ill $\beta$, Il6 are considered to repress the gene expression of both basolateral and canalicular bile transporters (27). Previous studies suggested that at early stages of inflammation, Ntcp down-regulation is regulated by Tnfa and $I l 1 \beta$ and at later stage by $I l 6(21,28)$. In these studies, $I l 6$ levels peaked at a later stage when compared with Tnfa levels, just as observed in this study. Tnfa or Ill $\beta$ also significantly decreases Fxr mRNA expression and binding activity to the IR-1 response element located in both human and rodent Bsep promoters (1).

In this study, we observed a correlation in time between inflammatory response and transporter expression. These results seem to coincide with those observed in LPS-induced cholestasis, with inflammation overriding possible adaptive changes due to the increase in bile acids. As transcriptional control of Ntcp, Bsep, and Mrp2 is mediated by the nuclear receptors $F x r$ and $P x r$, the decrease in Fxr/Pxr activation might be another mechanism diminishing expression of these transporters (1). The pattern of bile transporter regulation in the early stages of murine biliary atresia thus differs from acute noninflammatory cholestasis like bile duct ligation.

Only a few studies have addressed hepatobiliary transporter regulation in human biliary atresia (29). Chen et al. (30) investigated hepatobiliary transport in human biliary atresia at different stages of the disease. At early stages of biliary atresia-induced cholestasis in children, most basolateral and canalicular transporters and nuclear receptors were downregulated. This is similar to the findings of this study. This 
A

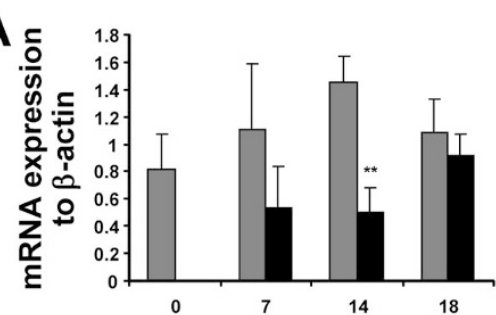

D

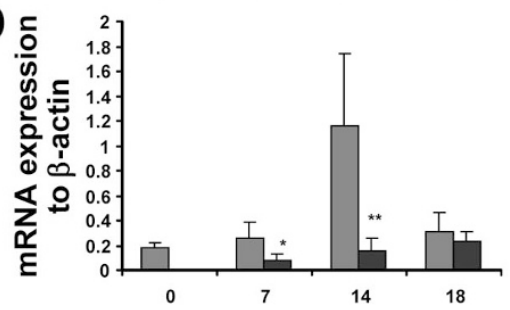

$\mathbf{G}_{\mathrm{s}}$

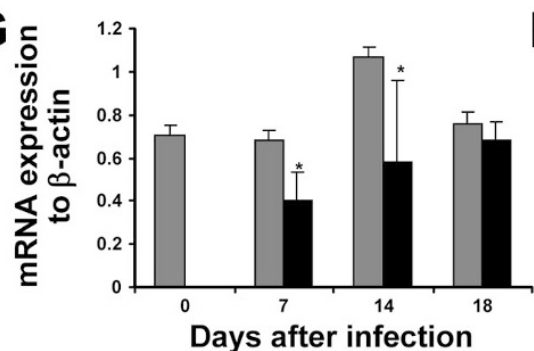

B

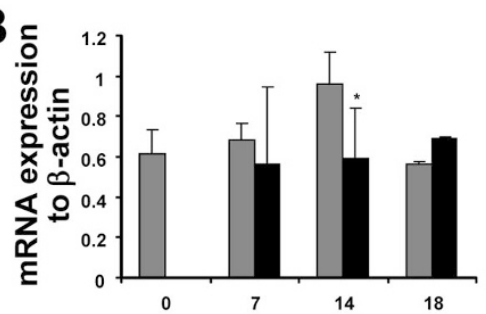

E

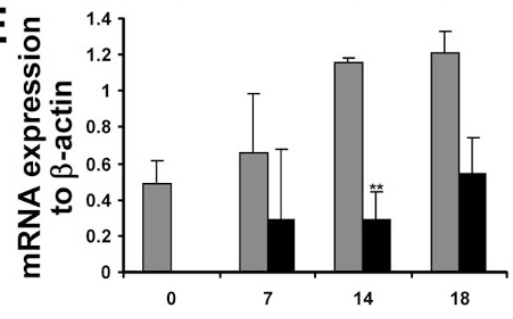

$\mathrm{H}$

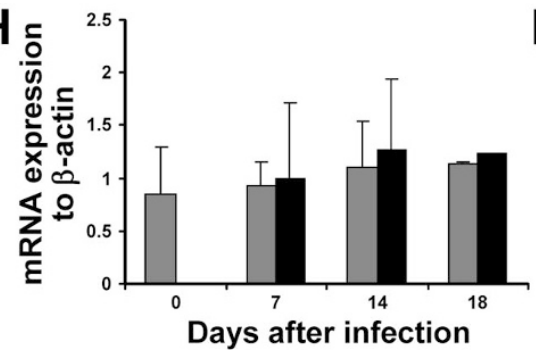

C

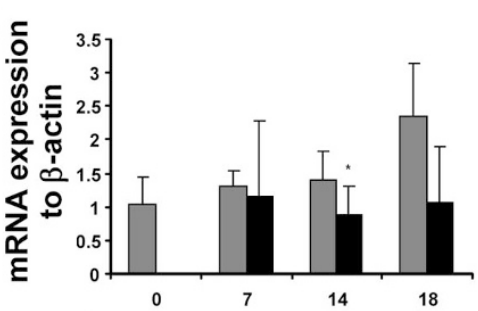

$\mathbf{F}$
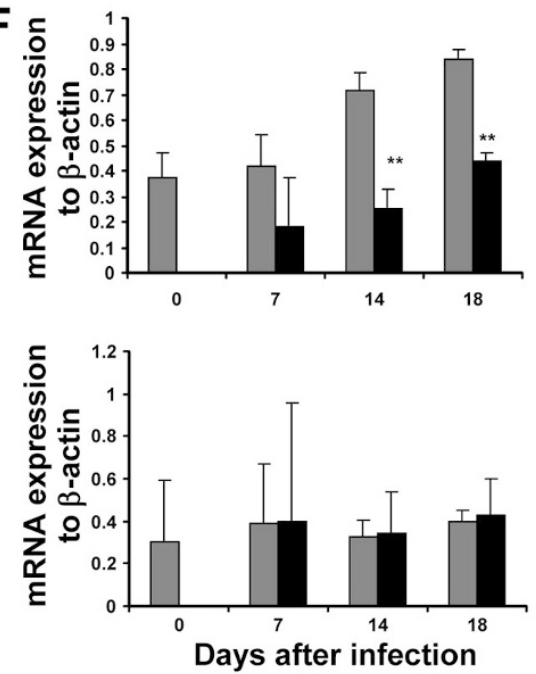

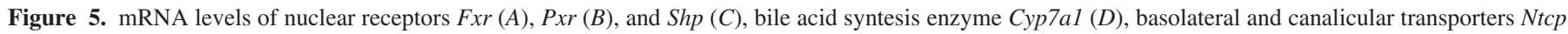

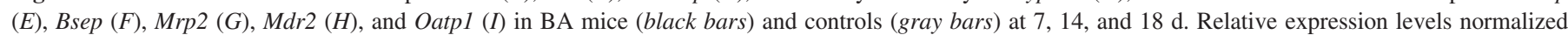
to the expression levels of $\beta$-actin are shown. ${ }^{*} p<0.05$ and ${ }^{*} * p<0.01$.

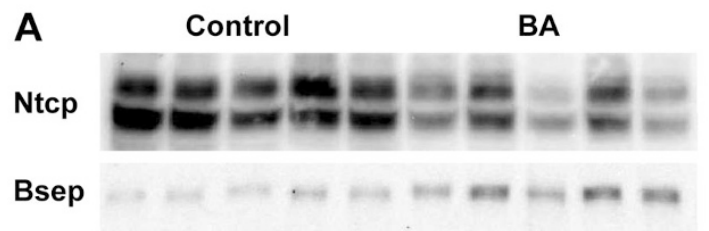

$50 \mathrm{kDa}$

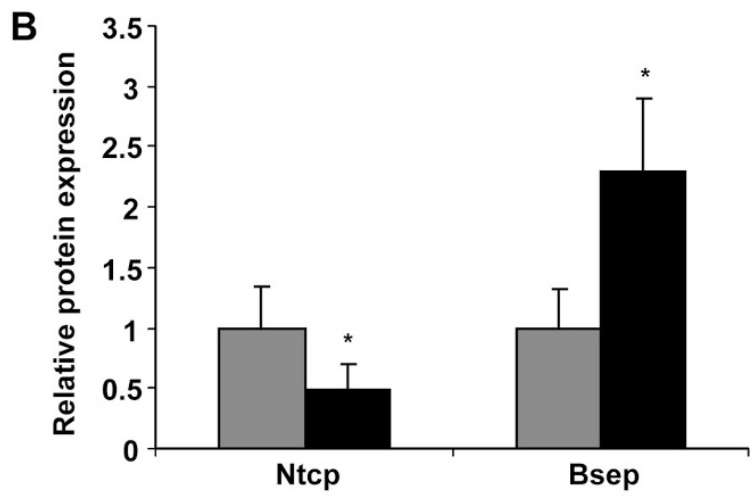

Figure 6. Western blots of Ntcp and Bsep in BA mice (black bars) and control mice (gray bars) at $14 \mathrm{~d}$. A: Western blot analysis of $50 \mathrm{kD} \mathrm{Ntcp}$ and $160 \mathrm{kD}$ Bsep from liver extracts in control and sick group. $B$ : The levels of protein expression were normalized to that of the control group, and the level of control group was set as 1.0. ${ }^{*} p<0.05$.

observation underlines the validity of the mouse model for studying the pathogenesis of biliary atresia. This overall response could act to decrease intracellular bile acid levels as well as to reduce the biliary pressure. However, in humans, Fxr-Bsep level tended to return to normal level at later stages and Pxr level remained decreased, which differs slightly from the results of our study. This difference might be due to relatively short survival period of the mice in this study.

We observed a difference between mRNA levels and protein levels of Bsep, in which the transcript level was downregulated whereas the translational level was up-regulated. The level of Bsep down-regulation might be underestimated by the western blot because the crude membrane techniques used in this study includes the endosomal compartment in which still a high level of Bsep might be present (19,31). Furthermore, retrieved transporter molecules may still be contained in this preparation (31). Western blotting using only basolateral or canalicular membrane preparations would yield more detailed information. Because of the small amount of liver tissue available from pups, those techniques are virtually impossible to apply in this particular type of study.

Although regulatory effects of inflammation on hepatobiliary transport have been proven both in vivo and in vitro $(1,21,28)$, the exact nature of this relation in vivo is yet not known as many inflammatory mediators might be involved. In this study, we have shown a temporal relation between inflammation and transporter down-regulation. In the absence of knowledge about the exact mechanism by which inflammation decreases hepatobiliary transport, a more direct causal relation cannot be established. Experiments to that extent, in our opinion, are not possible within the present model. For instance, anti-inflammatory drugs such as steroids have profound effects on hepatobiliary transport itself, probably via the glucocorticoid receptor (32). Blocking the inflammatory response using for instance Ifng knockout mice is also impos- 
sible, as these animals rarely develop BA (33). Therefore, we consider the present data the best possible answer to confirm the hypothesis that inflammation mediates downregulation of hepatobiliary transport during the early phases of BA development.

In conclusion, intrahepatic cholestasis due to downregulation of basolateral and canalicular hepatobiliary transporters is an early event in the development of biliary atresia. This down-regulation is probably due to the inflammatory process, which apparently overrides the regulatory effects of the concomitant increase in bile acids in the liver. The net result is intrahepatic cholestasis and liver damage, which occurs already before extrahepatic biliary obstruction. The results of this study are in line with preliminary studies in human, offering further proof of the validity of the mouse model and opening research approaches to mechanistical studies and possible therapeutic interventions.

Acknowledgments. We thank Professor Claus Petersen and Joachim Kuebler, Department of Pediatric Surgery, Hannover Medical School, Hannover, Germany, for the provision of the rhesus rotavirus and support for setting up the murine biliary atresia model; and Tineke van der Sluis, Department of Pathology, Frans Stellaard, Renze Boverhof, and Henk Wolters, Pediatric Research Laboratory, University Medical Center Groningen, for technical assistance and research support.

\section{REFERENCES}

1. Geier A, Wagner M, Dietrich CG, Trauner M 2007 Principles of hepatic organic anion transporter regulation during cholestasis, inflammation, and liver regeneration. Biochim Biophys Acta 1773:283-308

2. Jansen PL, Müller M 2000 The molecular genetics of familial intrahepatic cholestasis. Gut $47: 1-5$

3. Jansen PL, Müller M, Sturm E 2001 Genes and cholestasis. Hepatology 34:10671074

4. Trauner M, Fickert P, Zollner G 2001 Genetic disorders and molecular mechanisms in cholestatic liver disease-a clinical approach. Semin Gastrointest Dis 12:66-88

5. Goodwin B, Jones SA, Price RR, Watson MA, McKee DD, Moore LB, Galardi C, Wilson JG, Lewis MC, Roth ME, Maloney PR, Willson TM, Kliewer SA 2000 A regulatory cascade of the nuclear receptors FXR, SHP-1, and LRH-1 represses bile acid biosynthesis. Mol Cell 6:517-526

6. Lu TT, Makishima M, Repa JJ, Schoonjans K, Kerr TA, Auwerx J, Mangelsdorf DJ 2000 Molecular basis for feedback regulation of bile acid synthesis by nuclear receptors. Mol Cell 6:507-515

7. Sinal CJ, Tohkin M, Miyata M, Ward JM, Lambert G, Gonzalez FJ 2000 Targeted disruption of the nuclear receptor FXR/BAR impairs bile acid and lipid homeostasis. Cell 102:731-744

8. Petersen C, Kuske M, Bruns E, Biermanns D, Wussow PV, Mildenberger H 1998 Progress in developing animal models for biliary atresia. Eur J Pediatr Surg 8:137-141

9. Petersen C, Grasshoff S, Luciano L 1998 Diverse morphology of biliary atresia in an animal model. J Hepatol 28:603-607

10. Mack CL, Tucker RM, Sokol RJ, Karrer FM, Kotzin BL, Whitington PF, Miller SD 2004 Biliary atresia is associated with CD4+ Th1 cell-mediated portal tract inflammation. Pediatr Res 56:79-87

11. Mack CL, Tucker RM, Sokol RJ, Kotzin BL 2005 Armed CD4+ Th1 effector cells and activated macrophages participate in bile duct injury in murine biliary atresia. Clin Immunol 115:200-209
12. Mashige F, Imai K, Osuga T 1976 A simple and sensitive assay of total serum bile acids. Clin Chim Acta 70:79-86

13. Lowry OH, Rosebrough NJ, Farr AL, Randall RJ 1951 Protein measurement with the Folin phenol reagent. J Biol Chem 193:265-275

14. Stieger B, Hagenbuch B, Landmann L, Hochli M, Schroeder A, Meier PJ 1994 In situ localization of the hepatocytic $\mathrm{Na}+$ /Taurocholate cotransporting polypeptide in rat liver. Gastroenterology 107:1781-1787

15. Vos TA, Hooiveld GJ, Koning H, Childs S, Meijer DK, Moshage H, Jansen PL, Muller M 1998 Up-regulation of the multidrug resistance genes, Mrp1 and Mdr1b, and down-regulation of the organic anion transporter, Mrp2, and the bile salt transporter, Spgp, in endotoxemic rat liver. Hepatology 28:1637-1644

16. Gartung C, Ananthanarayanan M, Rahman MA, Schuele S, Nundy S, Soroka CJ, Stolz A, Suchy FJ, Boyer JL 1996 Down-regulation of expression and function of the rat liver $\mathrm{Na}+$ /bile acid cotransporter in extrahepatic cholestasis. Gastroenterology 110:199-209

17. Dumont M, Jacquemin E, D'Hont C, Descout C, Cresteil D, Haouzi D, Desrochers M, Stieger B, Hadchouel M, Erlinger S 1997 Expression of the liver Na+independent organic anion transporting polypeptide (oatp-1) in rats with bile duct ligation. J Hepatol 27:1051-1056

18. Trauner M, Arrese M, Soroka CJ, Ananthanarayanan M, Koeppel TA, Schlosser SF, Suchy FJ, Keppler D, Boyer JL 1997 The rat canalicular conjugate export pump (Mrp2) is down-regulated in intrahepatic and obstructive cholestasis. Gastroenterology 113:255-264

19. Lee JM, Trauner M, Soroka CJ, Stieger B, Meier PJ, Boyer JL 2000 Expression of the bile salt export pump is maintained after chronic cholestasis in the rat. Gastroenterology 118:163-172

20. Cherrington NJ, Slitt AL, Li N, Klaassen CD 2004 Lipopolysaccharide-mediated regulation of hepatic transporter mRNA levels in rats. Drug Metab Dispos 32:734741

21. Geier A, Dietrich CG, Voigt S, Kim SK, Gerloff T, Kullak-Ublick GA, Lorenzen J, Matern S, Gartung C 2003 Effects of proinflammatory cytokines on rat organic anion transporters during toxic liver injury and cholestasis. Hepatology 38:345-354

22. Green RM, Beier D, Gollan JL 1996 Regulation of hepatocyte bile salt transporters by endotoxin and inflammatory cytokines in rodents. Gastroenterology 111:193-198

23. Hartmann G, Cheung AK, Piquette-Miller M 2002 Inflammatory cytokines, but not bile acids, regulate expression of murine hepatic anion transporters in endotoxemia. J Pharmacol Exp Ther 303:273-281

24. Kim PK, Chen J, Andrejko KM, Deutschman CS 2000 Intraabdominal sepsis down-regulates transcription of sodium taurocholate cotransporter and multidrug resistance-associated protein in rats. Shock 14:176-181

25. Lund M, Kang L, Tygstrup N, Wolkoff AW, Ott P 1999 Effects of LPS on transport of indocyanine green and alanine uptake in perfused rat liver. Am J Physiol 277:G91-G100

26. Trauner M, Arrese M, Lee H, Boyer JL, Karpen SJ 1998 Endotoxin downregulates rat hepatic ntcp gene expression via decreased activity of critical transcription factors. J Clin Invest 101:2092-2100

27. Teng S, Piquette-Miller M 2008 Regulation of transporters by nuclear hormone receptors: implications during inflammation. Mol Pharm 5:67-76

28. Siewert E, Dietrich CG, Lammert F, Heinrich PC, Matern S, Gartung C, Geier A 2004 Interleukin-6 regulates hepatic transporters during acute-phase response. Biochem Biophys Res Commun 322:232-238

29. Shneider BL, Fox VL, Schwarz KB, Watson CL, Ananthanarayanan M, Thevananther S, Christie DM, Hardikar W, Setchell KD, Mieli-Vergani G, Suchy FJ, Mowat AP 1997 Hepatic basolateral sodium-dependent-bile acid transporter expression in two unusual cases of hypercholanemia and in extrahepatic biliary atresia. Hepatology 25:1176-1183

30. Chen HL, Liu YJ, Chen HL, Wu SH, Ni YH, Ho MC, Lai HS, Hsu WM, Hsu HY, Tseng HC, Jeng YM, Chang MH 2008 Expression of hepatocyte transporters and nuclear receptors in children with early and late-stage biliary atresia. Pediatr Res 63:667-673

31. Donner MG, Schumacher S, Warskulat U, Heinemann J, Haussinger D 2007 Periportal downregulation of Bsep and Mrp2 in experimental obstructive cholestasis is mediated by tnf-alpha and IL1-beta and is associated with periportal inflammation and cytokine secretion. J Hepatol 46:S120-S121

32. Eloranta JJ, Jung D, Kullak-Ublick GA 2006 The human Na+-taurocholate cotransporting polypeptide gene is activated by glucocorticoid receptor and peroxisome proliferator-activated receptor-gamma coactivator-1alpha, and suppressed by bile acids via a small heterodimer partner-dependent mechanism. Mol Endocrinol 20:65-79

33. Shivakumar P, Campbell KM, Sabla GE, Miethke A, Tiao G, McNeal MM, Ward RL, Bezerra JA 2004 Obstruction of extrahepatic bile ducts by lymphocytes is regulated by IFN-gamma in experimental biliary atresia. J Clin Invest 114:322-329 